\title{
Modal Psikologi Terhadap Peak Perfomance
}

\author{
Fitriana Pujarina dan Anisia Kumala \\ Fakultas Psikologi Universitas Muhammadiyah Prof. Dr. Hamka \\ fitrianapujarina@gmail.com, anisiakumala@gmail.com
}

\begin{abstract}
Indonesia is one of the countries that have great potential in the paralympic Olympics or sports for athletes with disabilities. Through the 2018 Asian Para Games held in Jakarta in October, proving the achievements of our athletes, Indonesia ranked fifth in this event. Therefore the purpose of this study was to determine the effect of Psychological Capital on Peak Performance in disabled athletes. This research method uses a quantitative approach. Respondents in this study consisted of 50 athletes with disabilities. The results of this study are to see the validity and reliability test using the Cronbach Alpha formula with an Alpha coefficient of 0.913 on the Psychological Capital scale and 0.92 on the Peak Performance scale. Data analysis in this study used a simple regression analysis technique with SPSS. The results of this study indicate that there is a significant influence between Psychological Capital on Peak Performance ( $R$ Square coefficient (R2) of 0.258 and probability value of 0,000). This means that the higher the Psychology Capital, the higher the Peak Performance of disabled athletes. The contribution of Psychological Capital to peak performance was $25.8 \%$.
\end{abstract}

Keyword: Psychological capital, peak performance

\begin{abstract}
Abstrak
Indonesia merupakan salah satu negara yang memiliki potensi besar di ajang olimpiade paralimpik atau ajang olahraga bagi atlet penyandang disabiltas. Melalui Asian Para Games 2018 yang diadakan di Jakarta pada bulan Oktober, membuktikan prestasi-prestasi yang diraih pada atlet kita, Indonesia menduduki peringkat kelima dalam ajang ini. Oleh karena itu tujuan pada penelitian ini adalah untuk mengetahui pengaruh Modal Psikologi terhadap Peak Performance pada atlet difabel. Metode penelitian ini menggunakan pendekatan kuantitatif. Responden dalam penelitian ini terdiri dari 50 atlet disabilitas. Hasil dari penelitian ini untuk melihat uji validitas dan realibilitas menggunakan formula Alpha Cronbach dengan koefisien Alpha sebesar 0.913 pada skala Modal Psikologi dan 0.92 pada skala Peak Performance. Analisis data pada penelitian ini menggunakan teknik analisis regresi sederhana dengan SPSS. Hasil penelitian ini menunjukkan bahwa adanya pengaruh yang signifikan antara Modal Psikologi terhadap Peak Performance (koefisien $\mathrm{R}$ Square $\left(\mathrm{R}^{2}\right)$ sebesar 0.258 dan probability value sebesar 0,000 ). Hal ini berarti bahwa semakin tinggi Modal Psikologi maka semakin tinggi Peak Performance pada atlet difabel. Kontribusi yang diberikan Modal Psikologi terhadap peak performance sebesar 25,8\%.
\end{abstract}

Kata Kunci: Modal Psikologi, Peak Performance 


\section{Pendahuluan}

Indonesia merupakan salah satu negara yang memiliki potensi besar di ajang olimpiade paralimpik atau ajang olahraga bagi atlet penyandang disabilitas. Melalui ASIAN PARA GAMES 2018 yang diadakan di Jakarta pada bulan oktober ini, membuktikan prestasi-prestasi yang diraih pada atlet kita, Indonesia menduduki peringkat kelima dalam ajang ini. Cukup dilihat bahwa adanya dorongan dan beberapa faktor yang membuat para atlet untuk terus yakin mencapai keberhasilan itu. Salah satunya keberhasilannya, adalah bagaimana para atlet untuk mengoptimalkan penampilan saat sedang dalam bertandingan, menyiapkan mental yang berani, serta sangat berartinya dukungan dari pihak mana pun untuk terus mendukung mereka dalam pertandingan.

Atlet diharuskan untuk memiliki kemampuan teknik, fisik dan perlu melakukan persiapan mental untuk mengembangkan kognitif, emosi dan strategi perilaku atlet. Namun bukan hanya para atlet yang memiliki tubuh yang sempurna saja yang mampu melakukan itu, para atlet difabel pun juga mampu mengendalikan emosi secara baik sehingga mereka juga bisa berprestasi.

Difabel adalah seseorang yang memiliki kelainan fisik atau mental yang sifatnya menganggu atau merupakan suatu hambatan baginya untuk melakukan kegiatan sehari-hari secara layak atau normal (John C Maxwell). Difabel merupakan singkatan dari frasa dalam Bahasa Inggris "Different Ability People". yang artinya Orang yang memiliki keterbatasan gerak. Mereka yang disebut sebagai difabel bukanlah kekurangan tetapi hanyalah berbedaan yang dimiliki. Mereka yang memiliki keterbatasan itupun mampu menunjukan kelebihan yang ada pada dirinya, mampu menjalani kehidupan sebagaimana orang pada biasanya. Seseorang yang memiliki keterbatasan fisik mereka juga memiliki hak yang sama, memiliki mimpi yang sama dengan seseorang yang normal, termasuk dalam pilhan untuk memilih profesi, sekalipun menjadi atlet.

Menurut Biro Humas dan Hukum Kementrian Pemuda dan Olahraga Republik Indonesia (2008, hlm 17) yang menjelaskan mengenai Undang-undang Republik Indonesia No 3 tahun 2005 tentang Sistem Keolahragaan Nasional, pasal 30 ayat 2 (dua) tentang pembinaan dan pengembangan olahraga penyandang cacat sebagai berikut; Pembinaan dan pengembangan olahraga penyandang cacat dilaksanakan dan diarahkan untuk meningkatkan kesehatan, rasa percaya diri dan prestasi olahraga. Mendapatkan pembinaan cabang olahraga sesuai dengan kondisi fisikdan/atau mental; dan mengikuti kejuaraan olahraga penyandang cacat yang bersifat daerah, nasional, dan internasional setelah melalui seleksi dan/atau kompetisi.

Maka dari itu penjelasan diatas adalah keterbatasan bukan penghalang bagi penyandang difabel untuk berprestasi, karena adanya pembinaan bagi para atlet yang penyandang disabilitas, jika memang dari orang tersebut memiliki kemauan yang keras untuk mencapai keberhasilan dan prestasi. Penampilan yang optimal harus dimiliki oleh atlet untuk mendapatkan hasil yang baik, untuk itu pada peak performance penting karena ini salah satu proses terbentuknya sikap mental dan tingkah laku yang dapat membuahkan hasil yang baik. Penampilan yang optimum yang dicapai oleh seorang atlet adalah sebuah perilaku psikologi olahraga.

Penampilan puncak (peak performance) adalah suatu kondisi optimal yang dimiliki seorang atlet saat melakukan segala bentuk kegiatan olahraga pada saat pertandingan. Penampilan puncak dibutuhkan oleh setiap pemain akan tetapi kondisi psikis atau kesiapan mental para atlet juga sangat dibutuhkan, sehingga dapat mempengaruhi pertandingan yang maksimal. Para atlet pada umumnya memiliki suatu kondisi yang dapat membantu mereka pada penampilannya. 
Garfield dan Bennett (Satiadarma, 2000:165) menjelaskan bahwa ada delapan kondisi spesifik yang mereka alami ketika mereka berada dalam peak performance yaitu: Mental rileks, Fisik rileks, Optimis, terpusat pada kekinian, Berenergi tinggi, Kesadaran tinggi, Terkendali, dan Terseludang (terlindungi dari gangguan).

Salah satu dalam kondisi spesifik tersebut terdapat pengembangan karakter (modal psikologi) yang dimiliki oleh individu yaitu optimis, keyakinan yang dimiliki seseorang untuk mencapai puncak keberhasilan. Penelitian ini bertujuan untuk mengetahui pengaruh modal psikologi terhadap Peak Performance pada atlet difabel. Manfaat penelitian dari segi teoritis ini diharapkan dapat memberikan informasi ilmiah bagi ilmu psikologi dan juga sebagai acuan penelitian selanjutnya tentang kemampuan para atlet untuk mengetahui seberapa penting kemampuan modal psikologi yang harus dimiliki oleh para atlet difabel, serta bertujuan untuk mengetahui pengaruh modal psikologi terhadap peak performance pada atlet difabel.

Serta manfaat penelitian dari segi praktis ini diharapkan dapat bermanfaat bagi masyarakat umum untuk mengenal lebih dekat tentang atlet difabel yang berprestasi dan supaya atlet mengetahui seberapa baik kemampuan kondisi fisik yang dimilikinya sehingga atlet mengerti bahwa kondisi fisik yang baik sangat besar sekali pengaruhnya terhadap kegiatan prestasi atlet tersebut. Serta agar para atlet menyadari kemampuan modal psikologi seperti apa yang harus dimiliki oleh para atlet difabel, dan yang terakhir bertujuan untuk melihat pengaruh modal psikologi terhadap peak performance pada atlet difabel.

\section{Modal Psikologi}

Variabel bebas menurut Sugiyono (2013:39) adalah variabel yang mempengaruhi atau yang menjadi sebab perubahannya atau timbulnya variabel terikat. Dalam penelitian ini, peneliti menetapkan untuk variabel independennya adalah Modal Psikologi.

Menurut Luthans, Youssef, dan Avolio (2007) Modal psikologi atau Psychology Capital adalah keadaan perkembangan psikologi positif seseorang dan ditandai oleh: (1) memilki kepercayaan diri (self efficacy) untuk bertahan dan melakukan sebuah usaha yang diperlukan untuk keberhasilannya dalam menyelesaikan tugas yang menantang; (2) membuat pemahaman positif (optimism) tentang keberhasilannya dimasa sekarang maupun di masa depan; (3) tekunlah dalam menuju tujuan dan bila perlu mengarahlah pada jalan tujuan (hope) agar berhasil; dan (4) ketika dilanda oleh masalah dan kesulitan, mempertahankan dan memantul kembali dan bahkan melampaui (resiliency) untuk mencapai kesuksesan.

\section{Komponen Modal Psikologi}

\section{Self efficacy}

Self effcacy adalah kepercayaan seseorang individu atas kemampuan yang dimiliki untuk menyelesaikan pekerjaannya (Bandura dalam Andika dan Madjid, 2012). Sedangkan menurut Andika dan Madjid (2012) Efikasi diri adalah kepercayaan (persepsi) seseorang mengenai kemampuan dalam dirinya untuk membentuk suatu perilaku. 


\section{Optimism}

Seligman (dalam Luthans, Youssef, dan Avolio, 2007) mendefinisikan optimis sebagai suatu cara menginterprestasi kejadian-kejadian positif sebagai suatu hal yang terjadi akibat diri sendiri, bersifat menetap, dan dapat terjadi dalam berbagai situasi; serta menginterprestasikan kejadiankejadian negatif sebagai suatu hal yang terjadi akibat hal-hal diluar diri, yang bersifat sementara, dan hanya terjadi pada situasi tertentu saja. Sedangkan menurut Scheier \& Carver (dalam Luthans, Youseef dan Avolio, 2007) optimis sebagai sifat perorangan, kecenderungan umum untuk mengharapkan kejadian yang menguntungkan dan hasil positif terjadi dimasa depan lebih sering daripada negatif.

\section{Hope}

Snyder, Irving dan Anderson (dalam Luthans et al, 2007) mendefinisikan harapan sebagai sebuah keadaan motivasi positif yang didasari oleh proses interaksi anatara (1) agency (kekuatan keinginan) komponen ini adalah energi untuk mencapai tujuan dan (2) pathways (perencanaan untuk mencapai tujuan) untuk mencapai kesuksesan

\section{Resiliency}

Masten dan Reed (dalam Luthans, Youseef dan Avolio, 2007) mendefinisikan ketahanan sebagai kelas fenomena yang ditandai oleh pola adaptasi positif dalam konteks kesulitan atau resiko yang signifikan. Masten dan Reed (dalam Luthans, Youseef dan Avolio, 2007) kembali mendefinisikan aset resiliensi sebagai karakteristik terukur dalam kelompok individu atau situasi mereka yang memprediksi hasil positif dimasa depan berdasarkan kriteria hasil yang spesifik.

\section{Faktor-faktor Modal Psikologi}

Menurut Luthans dan Youssef, 2017 terdapat faktor yang mempengaruhi modal psikologi, sebagai berikut: (1) Demografi yaitu seperti usia, masa kerja, etnis, atau jenis kelamin. (2) Karakteristik pekerjaan tertentu yang dapat mempengaruhi modal psikologi. (3) Kepribadian yaitu perbedaan individu seperti sifat dapat menjadi sumber modal psikologi. (4) Kepemimpinan yaitu adanya pengawasan dari pemimpin yang mempengaruhi modal psikologi.

\section{Peak Performance}

Variabel Terikat menurut Sugiyono (2013:39) adalah variabel yang dipengaruhi atau menjadi akibat karena adanya variabel independen. Dalam penelitian ini, peneliti menetapkan Peak Performance untuk sebagai variabel dependen.

Komarudin (2013) Penampilan puncak adalah kemampuan yang dicapai untuk mencapai kemampuan maksimal. Pencapaian puncak dapat membangun kepercayaan diri atlet. Zinser (dalam Komarudin, 2013) berpendapat bahwa penampilan puncak adalah korelasi langsung antara tingginya tingkat kepercayaan diri dan kinerja olahraga yang sukses. Penampilan puncak (peak performance) adalah suatu kondisi optimal yang dimiliki seorang atlet saat melakukan segala bentuk kegiatan olahraga pada saat pertandingan. 


\section{Aspek-aspek Peak Performance}

Garfied dan Bennett (dalam Williams 1998) menjelaskan bahwa ada delapan aspek Peak Performance. Aspek-aspek disaat atlet mengeluarkan kemampuan terbaiknya, diantara lain: (1) Mental rileks, adalah melakukan aktivitasnya dengan tenang, efektif, tidak melampaui batas waktu. (2) Fisik rileks adalah ketika kondisi ini atlet tidak merasakan adanya ketegangan, atau kesulitan dalam melakukan suatu gerakan tertentu. (3) Optimis, atlet merasa penuh percaya diri, yakin dengan apa yang dilakukanya akan membuahkan hasil sesuai dengan harapan. (4) Terpusat pada kekinian / Fokus dimana seorang atlet merasakan adanya keseimbangan psikofisik, segala sesuatu bekerja secara harmonis sebagai sesuatu kesatuan yang selaras dan berlangsung secara otomatis pada saat ini. (5) Berenergi tinggi, dalam kondisi puncak, atlet menikmati aktivitas dengan keterlibatan emosi yang tinggi. (6) Kesadaran tinggi, dalam kondisi ini atlet memiliki kesadaran yang tinggi tentang apa yang terjadi pada diri lawanya. (7) Terkendali, atlet seolah-olah tidak secara sengaja mengendalikan gerakan-gerakannya, namun segala sesuatu berlangsung seperti ada hal lain yang mengendalikan. (8) Terselubung, dalam kondisi ini atlet merasa seperti berada di dalam kepompong, sehingga ia mampu menutup penginderaannya dari gangguan-gangguan eksternal maupun internal.

Dari beberapa pendapat diatas, dapat disimpulkan bahwa aspek-aspek peak performance yaitu, mental rileks, fisik rileks, optimis, terpusat pada kekinian/fokus, berenergi tinggi, kesadaran tinggi, terkendali, dan terselubung.

\section{Metode}

\section{Partisipan Penelitian}

Penelitian ini menggunakan pendekatan kuantitatif. Menurut Sugiyono (2013: 13), metode penelitian kuantitatif dapat diartikan sebagai metode penelitian yang berlandaskan pada filsafat positivisme, digunakan untuk meneliti pada populasi atau sampel tertentu, teknik pengambilan pada umumnya dilakukan secara random, pengumpulan data menggunakan instrumen penelitian, analisis data bersifat kuantitatif/statistik dengan tujuan untuk menguji hipotesis yang telah ditetapkan.

Penelitian kuantitatif ini secara spesifik akan meneliti pengaruh, sehingga penelitian ini menggunakan analisis regresi sederhana. Populasi dalam penelitian ini adalah atlet difabel di Indonesia. Adapun sample yang digunakan berjumlah 50 orang atlet. Teknik sampling yang digunakan adalah Purposive Sampling dimana pengambilan sample dengan cara menetapkan ciriciri khusus yang sesuai dengan tujuan penelitian sehingga diharapkan dapat menjawab permasalahan pada penelitian.

\section{Instrument Penelitian}

Instrumen yang digunakan dalam penelitian ini adalah Psychology Capital Questionnaire (PCQ) Luthans, Youessef, dan Avolio (2007) untuk mengukur Modal Psikologi dengan nilai reliabilitas pada formula Alpha Cronbach sebesar 0.913 yang terdiri dari 20 item. Kemudian instrument 
penelitian yang digunakan dalam penelitian ini selanjutnya adalah Skala Peak Performance dengan nilai probabilitas pada Alpha Cronbach sebesar 0.902 yang terdiri dari 23 item.

\section{Teknik Analisa data}

Analisia data merupakan hal yang sangat penting dalam setiap penelitian. Analisis data dalam penelitian ini dilakukan menggunakan teknik analisis regresi sederhana dengan bantuan software statistic IBM SPSS Versi 22.

\section{Hasil}

\section{Tabel 1}

Model Summary

\begin{tabular}{lll}
\hline Model & $\mathrm{R}$ & R Square \\
\hline 1 & $0.508^{\mathrm{a}}$ & 0.258
\end{tabular}

a. Predictors:(constant),ModalPsikologi

Berdasarkan model summary menunjukan bahwa koefisien $\mathrm{R}$ sebesar 0.508 dan koefisien $\mathrm{R}$ Square sebesar 0.258

\section{Tabel 2}

Anova

\begin{tabular}{ll}
\hline $\mathrm{F}$ & Sig. \\
\hline 17.038 & $0.000^{\mathrm{b}}$
\end{tabular}

a.Dependent Variabel: PeakPerformance

b.Predictors: (constant): ModalPsikologi

Berdasarkan pada data Anova didapatkan koefisien $\mathrm{F}$ sebesar 17.038 dan probability value sebesar $0.000(\mathrm{P}<0.001)$ yang menunjukkan bahwa adanya pengaruh yang signifikan antara Modal Psikologi terhadap Peak Performance.

\section{Tabel 3}

Analisis Regresi Modal Psikologi

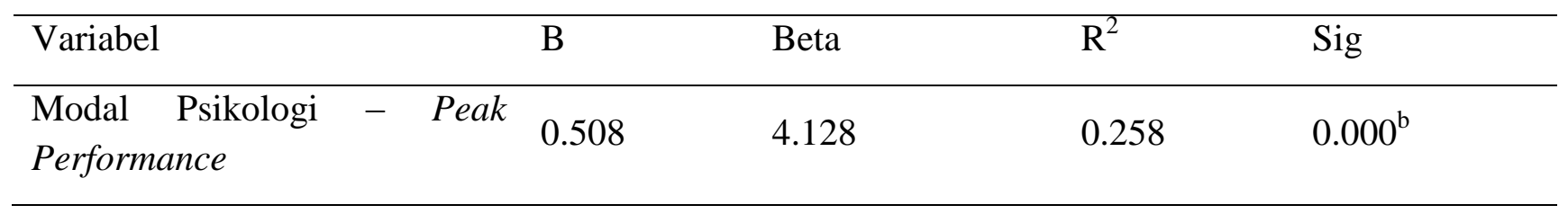

a.Dependent Variable: PeakPerformance 
Berdasarkan tabel diatas diperoleh nilai signifikansi sebesar 0,000. Hal ini dapat diartikan bahwa adanya pengaruh Modal Psikologi terhadap Peak Performance. Pembuktian untuk hipotesis tersebut dapat dilihat dari nilai signifikansi yang diperoleh lebih kecil dari nilai probabilitas 0,05 $(0,000<0,05)$.

Maka dari itu dapat disimpulkan bahwa hipotesis terdapat pengaruh antara Modal Psikologi terhadap Peak Performance atlet difabel. Sedangkan untuk nilai koefisien determinasi sebesar 0.258, maka dapat dartikan bahwa kontribusi yang diberikan Modal Psikologi terhadap Peak Performance sebesar $25,8 \%$.

\section{Pembahasan}

Berdasarkan hasil analisis dengan menggunakan SPSS pada tabel Model Summary menunjukan hasil R Square sebesar 0,258 yang berarti besar pengaruh modal Psikologi adalah 25,8\%. Nilai regresi antara variabel Modal Psikologi terhadap Peak Performance sebesar 0,508. Selain itu nilai signifikansi Modal Psikologi terhadap Peak Performance sebesar 0,000, nilai ini lebih kecil dibandingkan dengan nilai 0,05 . Hal tersebut dapat diartikan bahwa setiap meningkatnya satu nilai Modal Psikologi pada atlet difabel maka nilai peak performance akan menurun sebesar 0,508.

Dapat dilihat pada tabel Unstandardized Coefficients B Modal Psikologi terhadap Peak Performance sebesar 0,508 dengan dengan nilai signifikan sebesar 0,000 ( $\mathrm{P}<0,01)$. Hal ini menunjukan adanya efek positif dan signifikan terhadap Peak Performance. Secara umum hasil penelitian ini menunjukan adanya pengaruh yang signifikan antara variabel Modal Psikologi terhadap Peak Performance pada atlet difabel.

Hasil penelitian yang mendukung adanya pengaruh antara Modal Psikologi terhadap Peak Performance dilakukan oleh Muhammad Imam Fakhrurri (2018) yaitu mengenai Pengaruh kecemasan bertanding terhadap Peak Performance pada atlet bola basket. Hasil penelitian tersebut yaitu terdapat pengaruh negatif yang signifikan antara kecemasan terhadap peak performance. Hal ini ditunjukan dengan nilai koefisien regresi sebesar -0,794.

\section{Daftar Pustaka}

Fakhrurri, Muhammad Imam. (2018). Pengaruh Kecemasan Bertanding terhadap Peak Performance pada Atlet Bola Basket Universitas Islam Negeri Maulana Malik Ibrahim Malang. Skripsi. Fakultas Psikologi. Universitas Islam Negeri Maulana Malik Ibrahim Malang

Fatih Cetin-H. (2012). Nejat Basim. Journal Organizational Psychological Capital: A Scale Adaptation Study.

Kinanthi G.W dan Jannah M. (2016). Gambaran Kepribadian Hardiness Atlet Paralympic Atletik Lari Cepat. Jurnal Psikologi Teori dan Terapan. 06(2).

Komarudin. (2013). Makalah Gabungan Psikologi Olahraga. http://staff.uny.ac.id/sites/default/files/pendidikan/Komarudin,\%20M.A./Makalah\%20Gabung an\%20Psikologi\%20Olahraga.pdf. Diakses pada tanggal 11 Februari 2019. Pukul 17.00 WIB

Luthans et al. (2015). Psychological Capital and Beyond. New York: Oxford University Press. 
Nurfaizal. Yusmedi. (2016). Modal Psikologis Kreatif Creative Psychological Capital (CrePsyCap). Jurnal Pro Bisnis. 09(2). Hal 77

Rahmatunnisa, Ranti. (2018). Hubungan Budaya Pembelajaran dengan Modal Psikologi pada karyawan marketing. Skripsi. Fakultas Psikologi. Universitas Prof. Dr. Hamka.

Satiadarma, M, P. (2000). Dasar-dasar Psikologi Olahraga. Jakarta : Pustaka Sinar Harapan.

Sarwono, Jonathan. (2006). Metode Penelitian Kuantitatif \& Kualitatif. Graha ilmu. (hal. 26).

Sugiyono, 2013, Metodelogi Penelitian Kuantitatif, dan Kualitatif R\&D. (Bandung: ALFABETA).

Undang-undang Republik Indonesia Nomor 3 tahun 2005 tentang Sistem Keolahragaan Nasional .

Wells, Greg. (2016). Journal Peak Performance: A Literature Review. 